\title{
The Psychometric Properties of the Parent, Teacher and Student Versions of the Study Skills Scale
}

\author{
Sema KANER ${ }^{*}$ A. Dolunay KESÍKTAS ${ }^{* *}$
}

\begin{abstract}
This study aimed at developing the parent, teacher and student versions of The Study Skills Scale in order to assess the study skills of elementary school students. The construct validity of the three scales was tested by Principal Components Analysis. Item total correlations were also conducted, together with independent samples t-test in order to determine the meaningful difference between the top and the bottom $\% 27$ groups. The reliabilities of the scales and their subscales were analyzed using Cronbach Alpha, split half and test retest reliability estimates. The results taken together showed that all three scales had good psychometric properties and thus could be used to assess the study skills of elementary school students. A further analysis using the Pearson correlations showed consistencies among the three scales.
\end{abstract}

Key Words: Study skills, elementary school students, parent, teacher, scale

\section{SUMMARY}

Purpose and Significance: Study skills are behaviors that are considered to play an important role in one's independence and success throughout the life span. These skills range from finishing homework to listening strategies in class, which make up a whole bunch of behaviors that can be used in various settings such as school. Study skills are recommended by many authors to be learned during the early school years, which gradually become good habits later in life. Despite such considerations, few attempts to tackle these skills for young

*Prof. Dr., Faculty of Educational Sciences, Department of Special Education, kaner@education.ankara.edu.tr

** Specialist, Ankara Univetsity, Center of Special Education Research and Practice, aysedolunay@yahoo.com 
(elementary school) populations have been made and literature seems to be more concerned with the study skills of high school and university students. There also lies the problem of measuring the study skills of elementary school students, which can be thought to be the first step in preparing programs to enhance students' study skills. Thus there seems to be a need to develop instruments for measuring the study skills of elementary school students.

The last few decades have shown the importance of the role of the students, the parents and the teachers in the process of studying. Therefore a comprehensive assessment should involve all parties.

This study aimed at developing the parent, teacher and student versions of the Study Skills Scale in order to assess the study skills of elementary school students.

Methods: The sample consists of 588 elementary and middle school students, 555 parents and 98 teachers residing in Ankara, Adana and Kırıkkale. Data were used to conduct indepth validity and reliability studies.

The construct validity of the three scales was tested via Principal Components Analysis. Item total correlations were also conducted, together with independent samples t-test in order to determine the meaningful difference between the top and the bottom $\% 27$ percentiles. The reliabilities of the scales and their subscales were analyzed using Cronbach Alpha, split half and test retest reliability coefficients. The consistencies among the three scales were analyzed using the Pearson correlation coefficient.

Results: The results showed that all versions of the Study Skills Scale displayed good psychometric properties. The Parent, Teacher and Student versions had 6,5 and 6 factors and a total of 43,31 and 55 items respectively and some of the factors showed similarities across the scales.

A further analysis using the Pearson correlations showed rating consistencies among the three scales.

Discussion and Conclusions: According to the results, all versions of the Study Skills Scale can be used to assess the study skills of elementary school students. Although some factors were incongruent with the results of different studies, two reasons for this can be proposed. Firstly, our scales covered a wide range of skills compared to the literature examining only some portion of study skills. Secondly, literature mostly presents information for high school and university students and thus is different from our sample, at least in terms of age.

The scales developed in this study can be used as a primary step in preparing study skills programs for elementary school students. Further research should also tackle the issue of developing similar instruments for a variety of populations such as children with low SES or special educational needs. 


\section{Ders Çalışma Becerileri Ölçeği Ana-Baba, Öğretmen ve Öğrenci Formlarının Psikometrik Özellikleri}

\author{
Sema KANER ${ }^{*}$
}

\section{A. Dolunay KESİKTAS ${ }^{* *}$}

ÖZ.Bu çalışmada, ilköğretim öğrencilerinin ders çalışma becerilerinin ana-babalar, öğretmenler ve öğrenciler tarafindan değerlendirilmesini sağlamak amacıyla Ders Çalışma Becerilerini Değerlendirme Ölçeği/Ana-Baba Formu (DÇBDÖ/ABF), Ders Çalışma Becerilerini Değerlendirme Ölçeği/Öğretmen Formu (DÇBDÖ/ÖF) ve Ders Çalışma Becerilerini Değerlendirme Ölçeği/Öğrenci Formu (DÇBDÖ/ÖĞRF) geliştirilmiş ve bu araçların psikometrik özellikleriyle ilgili sonuçlar özetlenmiştir. Üç ölçeğin yapı geçerliğini belirlemek amacıyla Temel Bileşenler Analizi uygulanmıştır. Ayrıca, her bir ölçek için madde-toplam korelasyonları ve alt ve üst \% 27'lik gruplarda ilişkisiz ölçümler için t testi uygulanmıştır. DÇBDÖ ana-baba, öğretmen ve öğrenci formlarının hem alt ölçekleri hem de ölçeklerin tümü için Cronbach Alpha ve testyeniden test teknikleri yoluyla güvenirlikleri incelenmiştir. Tüm bu analizler DÇBDÖ’nin üç formunun da ilköğretim öğrencilerinin ders çalışma becerileri değerlendirme çalışmalarında kullanılabilmesi için yeterli psikometrik özelliklere sahip olduğunu göstermektedir. Ayrıca, ölçme araçları arası ikili korelasyonlar hesaplanmış ve üç bilgi kaynağının değerlendirmeleri arasında tutarlılık olduğu belirlenmiş̧tir.

Anahtar Sözcükler: Ders çalı̧̧ma becerileri, ilköğretim öğrencileri, ana-baba, öğretmen, ölçek

\footnotetext{
${ }^{*}$ Prof. Dr. Ankara Üniversitesi Eğitim Bilimleri Fakültesi, Özel Eğitim Bölümü, kaner@education.ankara.edu.tr

${ }^{* *}$ Uzm. Ankara Üniversitesi, Özel Eğitim Araştırma ve Uygulama Merkezi, aysedolunay@yahoo.com
} 


\section{GíRIS}

Yaşam boyu devam eden ve bireyin kendi çabalarıyla gerçekleştirdiği öğrenme etkinlikleri, çağdaş toplumların temel talepleri arasında yer almaktadır (Yıldırım, Doğanay ve Türkoğlu, 2000). Öğrenmenin önemli bir sürecini kapsayan okul yıllarında, bireyin öğrenme etkinliklerini daha programlı yürütmesi, bir diğer deyişle öğrenmek için ders çalışma becerilerini kazanmış olması gerekmektedir. Okul yıllarında kazanılan bu alışkanlıkların, bireyi okul sonrası yaşamda da başarıya götüreceği belirtilmekte (Thomas, 1993; Yeşilyaprak, 2000; Yıldırım ve diğ., 2000), bu da ders çalışma becerilerinin yaşam döngüsündeki önemini ortaya koymaktadir.

Ders çalışma becerileri genel olarak "öğrenme amacıyla belirli tekniklerin etkili bir biçimde kullanılması" olarak tanımlanmakta (Thomas, 1993; Uluğ, 2000; Yıldırım ve diğ., 2000) ve planlı çalışma, çalışma ortamını düzenleme, etkili okuma, ders dinleme, not tutma, etkili yazılı anlatım, derse aktif katılma, ödev yapma, sınavlara hazırlanma ve sınavlara girme başl1kları altında incelenmektedir (Dodge, 1994; McEwan, 1996; Smith, 2000; Thomas, 1993; Uluğ, 2000; Yeşilyaprak, 2000; Yıldırım ve diğ., 2000). Bunlar ders çalışma becerilerinin genel kategorilerini oluşturmakta ve bu beceriler okula zamanında gitme, derse devam etme, iyi beslenme, dinlenme ve uykuya yeterli zaman ayırma gibi birtakım davranışlarla da desteklenmektedir (Uluğ, 2000; Yıldırım ve diğ., 2000).

Ders çalışma becerilerinin her birinin tek başına önemli beceriler olmakla birlikte, birbirlerinden bağımsız olmadıklarını belirtmek yerinde olacaktır. Alan yazında da, söz konusu becerilerin birbirlerini destekleyici nitelikte oldukları ve en üst düzeyde başarının, tümünün uyumlu bir şekilde bir arada kullanılması ile yakından ilişkili olduğu sıklıkla vurgulanmaktadır (Gettinger ve Seibert, 2002; Uluğ, 2000; Yıldırım ve diğ., 2000).

Ders çalışma becerilerinin insan yaşamında oynadığı önemli rol, öğrencilerin erken okul yıllarından itibaren bu alanda kendilerini geliştirmeleri gerekliliğini doğurmuştur (Thomas, 1993; Yeşilyaprak, 2000). Yeşilyaprak (2000), ilköğretim öğrencilerinin temel gereksinimleri arasında, öğrenmeyle ilgili olumlu tutumlar geliştirme, öğrenmeyi kolaylaştırma, karar verme ve amaç belirleme gibi unsurların yer aldığını belirtmektedir. Ders çalışma becerileri, bu davranışların geliştirilmesinde de önemli bir etken niteliği taşımaktadır. Dolayısıyla, ders çalışma alışkanlıklarının kazanılması ilköğretim döneminde ayrı bir öneme sahiptir.

İlköğretim öğrencilerinin ders çalışma becerilerini desteklemede ilk adım, kuşkusuz ki bu öğrencilerin ders çalışma becerilerini kazanım 
düzeylerini belirlemektir. Yabancı alan yazın incelendiğinde, ders çalışma becerileri ölçeklerinin genellikle lise ve üniversite öğrencilerine yönelik olduğu görülmektedir (Dodeen, 2008; Kiewra, 2002; Turnbough ve Christenberry, 1997; Xu, 2008). Türkiye'de ise bu alanda çalıșmalara rastlanmakla birlikte, ilköğretim düzeyindeki öğrencilere yönelik uyarlanan ya da özgün olarak geliştirilen ölçme araçlarının sınırlı sayıda olduğu (Demiroğlu-Memiş, 2007; Uluğ, 1981), geliştirilen ölçme araçlarının, yurt dışında olduğu gibi çoğunlukla üniversite öğrencilerini hedeflediği (Aksu ve Paykoç, 1995; Arıkan, 1999; Karabınar, 2000; Serbest, 1991; Teker, 2002) görülmektedir. Dolayısıyla, ülkemizde ilköğretim öğrencilerinin kendi ders çalışma becerilerini nasıl değerlendirdiklerini belirlemek, üzerinde durulması gereken bir konu haline gelmiştir.

Geçmiş yıllarda, ders çalışmada en büyük payın öğrenciye düştüğü, bunu azalan oranda ana-baba ve öğretmenin takip ettiği görüşünün, eğitimciler arasında yaygın olduğu gözlenmektedir (Babadoğan, 2002). Öğretmenin temel görevinin ders anlatmak olduğu inanışı, ders çalışma etkinliklerini tamamen ev ortamına taşımakta ve bu sorumluluğu öğrenci ve ana-babaya yüklemekteydi. Bu yaklaşım günümüzde öğrenci ve ana-baba kadar, öğretmenin de ders çalışma sürecinde önemli görevleri olduğu varsayımına dayanılarak terk edilmiştir. Dolayısıyla ders çalışma öğrenci, ana-baba ve öğretmen arasında süre giden bir çabanın ürünü olmuştur (Babadoğan, 2002; Smith, Teske ve Gossmeyer, 2000).

$\mathrm{Bu}$ çağdaş yaklaşımdan yola çıkarak, ders çalışma becerilerine yönelik araştırmalarda, ana-baba ve ögretmenlerin de önemli bilgi kaynakları olduklarını söylemek doğru olacaktır. Araştırmalar her iki kaynağın, öğrencilerin ders çalışma becerilerini, farklı ortamlara göre olsa dahi benzer değerlendirdikleri ancak öğretmen değerlendirmelerinin ana-babalarınkine kıyasla daha olumsuz olduğu, bunun yanında öğrenci değerlendirmelerinin ana-baba ve öğretmenlere kıyasla daha olumlu olduğu yönünde sonuçlara işaret etmektedir (Anday-Porter, Henne ve Horan, 2000; Smith ve diğ., 2000; Soderlund ve Bursuck, 1995). Buna göre, öğretmen ve ana-baba değerlendirmeleri öğrencilerin farklı ortamlardaki çalışma davranışlarını yansıtsa da, öğrencilerin ders çalışılan tüm ortamlarda sorunlar yaşadıklarını ortaya koymaları bakımından önemlidir. Öğrenci değerlendirmelerinin, öğretmen ve ana-baba değerlendirmelerine kıyasla daha olumlu olması da, öğrencilerin kendilerindeki birtakım yetersizlikleri algılamada sorun yaşamaları olarak değerlendirilebilir ve bu noktada öğretmen ve ana-baba değerlendirmeleri öğrencilerin yaşadıkları güçlükleri ortaya çıkarmaları bakımından önemli olabilir. Dolayısıyla öğrencilerin olduğu kadar, ana- 
babaların ve öğretmenlerin de değerlendirmelerine başvurmak gerekmektedir.

Öğrencilere ilişkin Türkiye'de geliştirilen ölçme araçları ile ilgili yukarıda belirtilen sınırlılıklar, öğretmenler ve ana-babalar için daha da ciddi boyutlardadır. Nitekim alan yazın incelendiğinde, ana-babaların çocuklarının ders çalışma becerilerini değerlendirmelerine ilişkin ölçme araçlarına rastlanmamaktadır. Öğretmen değerlendirmelerine ilişkin geliştirilen ölçme araçlarının ise sınırla sayıda olduğu (Akçamete, Gürgür, Kış ve Kayaoğlu, 2002; Arıkan, 1999) görülmektedir. Dolayısıyla ana-babaların ve öğretmenlerin, öğrencilerin ders çalışma becerilerini değerlendirmelerine ilişkin ölçme araçlarına gereksinim vardır.

Ders çalışma alışkanlıkları konusunda öğrencilerin kendilerini değerlendirmelerinin yanı sıra, ana-babaların çocuklarını, öğretmenlerin de öğrencilerini değerlendirmeleri önem teşkil etmektedir. Elde edilecek söz konusu bilgiler doğrultusunda, öğrencilerin ders çalışma becerilerine ilişkin geniş bir bakış açısı edinmek ve bu doğrultuda öğrencileri ders çalışma becerileri açısından desteklemek mümkün olacaktır. Ülkemizde, ilköğretim öğrencilerine yönelik yapılan araştırmaların, farklı bilgi kaynaklarını bir arada kullanmadıkları dikkat çekmektedir (Akçamete ve diğ., 2002; Uluğ, 1981). Bu nedenle, ana-babaların, öğretmenlerin ve öğrencilerin görüşlerine bir arada ulaşmak ve çok yönlü bir durum saptaması yapmak amacıyla, üç bilgi kaynağının öğrencilerin ders çalışma becerilerini değerlendirmelerine ilişkin ölçme araçlarına gereksinim olduğu sonucuna varılmıştır. Dolayısıyla bu araştırmanın amacını, ilköğretim ögrencilerinin ders çalışma becerilerini belirlemek için öğrencilere ve bu öğrencilerin ana-babaları ve öğretmenlerine yönelik ölçme araçlarının geliştirilmesi ve üç bilgi kaynağının değerlendirmeleri arasındaki ilişkilerin incelenmesi oluşturmuştur.

\section{YÖNTEM}

\section{Örneklem}

Araştırma grubunu, kolay ulaşılabilir gruplar yoluyla Ankara (12 okul), Adana (3 okul) ve Kırıkkale (1 okul) illerinde yer alan ve bulundukları semtlere göre alt, orta ve üst sosyoekonomik düzeyi yansıttıkları varsayılan 16 ilköğretim okulunun 2.-8. sınıflarına devam eden, 8-15 yaşları arasındaki 800 öğrenci ile bu öğrencilerin ana-babaları ve sınıf öğretmenleri oluşturmuştur. Uygun yanıtlanmayan ve geri dönmeyen formların elenmesinden sonra 588 öğrenci, 555 ana-baba ve 98 sinıf öğretmeninden kullanılabilir veriler elde edilmiştir. Öğrencilerin 295'i kız (\%51.1), 281'i (\%48.9) erkektir. On bir öğrenciden cinsiyete ve bir öğrenciden yaşa ilişkin 
bilgi alınamamıştır. Tüm grubun, kız öğrencilerin ve erkek öğrencilerin yaş ortalamaları sirasiyla $11.43 \quad(\mathrm{ss}=1.80), 11.36 \quad(\mathrm{ss}=1.78)$ ve 11.46 'dir $(\mathrm{ss}=1.82)$.

Ana-baba ölçeğini dolduran katılımcıların yaklaşık yarısını anneler $(n=317, \% 53.9), \% 35.2$ 'sini $(n=207)$ ise babalar oluşturmuştur. Ölçeği birlikte yanıtladıklarını bildiren anne ve babaların sayısı ise 47'dir (\%8). Ana-babaların dışında abla, ağabey, büyükanne ve büyükbaba gibi birinci derece akrabaların yanıtladıkları ölçek sayısı 8'dir (\%1.4). Dokuz ölçekten ise (\%1.5) katılımcıların kimliklerine ilişkin bilgi edinilememiştir.

Araştırmaya katılan öğretmenlerin tümünü ilköğretim kademesinde çalışan sınıf öğretmenleri oluşturmaktadır. Tüm öğretmenlere, kendi sınıf listelerinde yer alan ilk beş öğrenciyi ders çalışma becerileri bakımından değerlendirmeleri istenmiş ve böylelikle 98 sinıf öğretmeninin toplam 389 öğrenciyi değerlendirmeleri sağlanmıştır.

\section{Veri Toplama Araçlart}

$\mathrm{Bu}$ çalışmada, öğrencilerin çalışma becerilerini farklı bilgi kaynaklarına göre değerlendirmek amacıyla, araştırmacılar tarafindan üç ölçme aracı geliştirilmiştir. Bu araçlardan Çalışma Becerilerini Değerlendirme Ölçeği / Ana-Baba Formu (ÇBDÖ/ABF) ana-babaların çocuklarının ders çalışma becerilerine ilişkin değerlendirmelerini, Çalışma Becerilerini Değerlendirme Ölçeği / Öğretmen Formu (ÇBDÖ/ÖF) sınıf öğretmenlerinin öğrencilerinin ders çalışma becerilerine ilişkin değerlendirmelerini, Çalışma Becerilerini Değerlendirme Ölçeği / Öğrenci Formu (ÇBDÖ/ÖĞRF) ise öğrencilerin kendi ders çalışma becerilerine ilişkin değerlendirmelerini belirlemeyi hedeflemektedir.

\section{Çalışma Becerilerini Değerlendirme Ölçeği / Ana-Baba Formu (ÇBDÖ/ABF)}

Ana-babaların çocuklarının ders çalışma becerilerini değerlendirmek amacıyla geliştirilen ÇBDÖ/ABF, 43 maddeden ve altı alt ölçekten oluşmaktadır.

1. Sistemli ve Organize Çalışma (SOÇ): Yirmi maddeden oluşan bu alt ölçekte, çocuğun okulda öğrendiklerini evde tekrarlaması, bir metni sistematik olarak okuması ve planlı bir şekilde sınavlara hazırlanması ile ilgili davranışlar değerlendirilmektedir. $\mathrm{Bu}$ ölçeğe örnek bazı maddeler "O gün sınıfta işlenen konuları evde tekrar eder" ve "Bir metni okumaya başlamadan önce başl1k, ara başlık, giriş, özet gibi bölümleri inceleyerek konuyla ilgili ön bilgi edinir" dir. 
2. Temizlik ve Düzen (TD): $\mathrm{Bu}$ alt ölçekte, çocuğun derste tuttuğu notların, ödevlerinin, defterlerinin ve çantasının temiz ve düzenli olduğunu ifade eden beş madde bulunmaktadır. Örneğin "Ödevlerini temiz ve düzenli yapar" ve "Defterleri temiz ve düzenlidir."

3. Çalışma Ortamı (ÇO): Çalışma ortamı alt ölçeğinde, çocuğun evdeki çalışma ortamını değerlendiren beş madde yer almaktadır. Örneğin "Derslerine çalışabileceği bir masa ve sandalyesi vardır" ve "Derslerine uygun sıcaklığın ve iyi ışıklandırmanın olduğu bir ortamda çalışır."

4. Ev Ödevleri (Ë̈): Beş maddeden oluşan bu alt ölçekte, ev ödevlerini yapmaya ilişkin olumsuz davranışlar değerlendirilmektedir. Bu ölçeğe örnek bazı maddeler "Bir ödevini bitirmeden diğerine başlamaz" ve "Ev ödevlerini yapmayı reddeder" dir.

5. Kaynaklara Başvurma (KB): Bu alt ölçek, ödev ve projeler üzerinde çalışırken, öğrencinin yardımcı kaynaklara ulaşmasıyla ilgili beş maddeyi içermektedir. Örneğin "Yaptığı ödevleri bir başkasına kontrol ettirir" ve "Sınavlarına birlikte çalışırız."

6. Dinlenme (D): Dinlenme alt ölçeğinde ise, çocuğun uyku ve dinlenmeye yeterli zaman ayırması ve okula zamanında gitmesi ile ilgili üç madde yer almaktadır. Örneğin "Okula zamanında gider."

Ölçek üçlü dereceleme ölçeğidir (1=hiçbir zaman, 2=bazen, 3=her zaman). Bazı maddeler $(32,33,34,35)$ olumsuz yönde ifade edildikleri için bu maddelerde puanlama tersine yapılmaktadır $(1=$ her zaman, $2=$ bazen, $3=$ hiçbir zaman). Bu ölçekten alınabilecek en yüksek puan, madde sayısının 3 ile çarpımı olan 129, en düşük puan ise madde sayısının 1 ile çarpımı olan 43'tür. Yüksek puan almak, ana-baba değerlendirmesine göre çocuğun olumlu çalışma becerilerine sahip olduğuna işaret etmektedir.

\section{Çalışma Becerilerini Değerlendirme Ölçeği / Öğretmen Formu (ÇBDÖ/ÖF)}

Öğretmenlerin öğrencilerinin ders çalışma becerilerini değerlendirmek amaciyla geliştirilen ÇBDÖ/ÖF, 31 maddeden ve beş alt ölçekten oluşmaktadır.

1. Derse Katılım / Etkili Çalışma (DK/EÇ): On iki maddeden oluşan bu alt ölçekte, sınıf öğretmeninin öğrenciyi derse katılım ve etkili ders çalışma alanlarında değerlendirmesi hedeflenmiştir. $\mathrm{Bu}$ alt ölçeğe örnek bazı maddeler "Sınıf içi bireysel ve grup etkinliklerine katılır" ve "Verilen ödevler ile ilgili sorular sorar" dır. 
2. Temizlik ve Düzen (TD): Bu alt ölçek, sınıf öğretmeninin öğrencinin ödevlerlerini temiz ve düzenli yapması ile defterlerini, çantasını ve sırasını temiz ve düzenli kullanmasına ilişkin davranışlarını değerlendirmesini içeren dokuz maddeden oluşmaktadır. Örneğin "Sırasını temiz tutar" ve "Derste aldığı notlar okunaklıdır”.

3. Not Tutma / Sınava Girme (NT/SG): Bu alt ölçekte, derste not tutma ve sınav esnasinda gerekenleri yerine getirme ile ilgili beş madde bulunmaktadır. Örneğin "Derste öğretmenin anlattıklarını defterine yazar" ve "Sinava zamanında gelir."

4. Ödev Defteri Tutma (ÖDT): Üç maddeden oluşan bu alt ölçekte, ödev defteri bulundurma ve verilen ödevleri bu deftere yazma davranışı değerlendirilmektedir. Bu ölçeğe örnek bir madde "Sınıfta verilen ödevleri ödev defterine yazar" dır.

5. Okula Devam (OD): Bu alt ölçekte ise, okula ve derse devamı değerlendiren iki madde bulunmaktadır. Örneğin "Okula zamanında gelir."

Ölçek üçlü dereceleme ölçeğidir (1=hiçbir zaman, 2=bazen, 3=her zaman). Bu ölçekten alınabilecek en yüksek puan, madde sayısının 3 ile çarpımı olan 93, en düşük puan ise madde sayısının 1 ile çarpımı olan 31'dir. Yüksek puan almak, öğrencinin ders çalışma becerilerinin sınıf öğretmeni tarafindan olumlu olarak değerlendirildiği anlamına gelmektedir.

\section{Çalış̧ma Becerilerini Değerlendirme Ölçeği / Öğrenci Formu (ÇBDÖ/ÖĞRF)}

Öğrencilerinin kendi ders çalışma becerilerini değerlendirmek amacıyla geliştirilen ÇBDÖ/ÖĞRF, 55 maddeden ve altı alt ölçekten oluşmaktadır.

1. Etkili Ödev Yapma ve Sinavlara Hazırlanma (EÖY/SH): Bu alt ölçek, ödev yaparken ve sinavlara hazırlanırken etkili stratejilerden yararlanmayı değerlendiren 18 maddeden oluşmaktadır. Bu ölçeğe örnek bazı maddeler "Ödevlerimi zamanında ve eksiksiz bitiririm" ve "Bir sonraki sınava, yaptığım hataları görerek hazırlanırım" dır.

2. Sistemli ve Organize Çalışma (SOÇ): On maddeden oluşan bu alt ölçekte, çalışma planı yapma ve okuma ödevleri ile ilgili sistemli çalışma becerileri değerlendirilmektedir. Örneğin "Kendime haftalık çalışma planı yaparım" ve "O gün sinıfta işlenen konuları evde tekrar ederim."

3. Öğrenmede Karşılaşılan Güçlükler (ÖKG): $\mathrm{Bu}$ alt boyutta, öğrencinin ders dinleme ve ödev yapma gibi konularda yaşadığ güçlükleri değerlendiren 10 madde yer almaktadır. Örneğin "Yeterince hızlı okuyamam" ve "Öğrendiğim konuları çok çabuk unutuyorum." 
4. Çalışma Ortamını Düzenleme (ÇOD): Sekiz maddeden oluşan bu alt ölçekte, okul için gerekli araç-gereçleri bulundurma ve çalış1lan ortamın uygun şekilde düzenlenmesi değerlendirilmektedir. Bu ölçeğe örnek bazı maddeler "Evde hep aynı yerde ders çalışırım" ve "Çantam ve defterlerim temiz ve düzenlidir" dir.

5. Yardım İsteme (Yİ): Bu alt ölçek, öğrencinin akademik çalışmalar sırasında güçlük çektiği durumlarda başkalarından yardım isteme davranışlarını değerlendiren dört maddeden oluşmaktadır. Örneğin "Yaptığım ödevleri anneme veya babama kontrol ettiririm" ve "Sinavlara annemle veya babamla birlikte çalışırım."

6. Düzenlilik ve Uygun Sınıf İçi Davranış (D/USD): Beş maddeden oluşan bu alt ölçekte ise, ödevleri düzenli yapma ve sınıf ortamında ders dışı etkinliklere girmekten kaçınma davranışları değerlendirilmektedir. Bu ölçeğe örnek bazı maddeler "Bir ödevimi bitirmeden diğerine başlamam" ve "Sınıf arkadaşlarımın dersi dinlemelerini engelleyecek davranışlarda bulunmam" dir.

Bu ölçek de, diğerleri gibi üçlü dereceleme ölçeğidir (1=hiçbir zaman, $2=$ bazen, $3=$ her zaman). Baz1 maddeler $(6,11,15,20,23,24,28,33,48,64$, 74 ve 75 ) olumsuz yönde ifade edildikleri için bu maddelerde puanlama tersine yapılmaktadır ( $1=$ her zaman, $2=$ bazen, $3=$ hiçbir zaman). Bu ölçekten alınabilecek en yüksek puan, madde sayısının 3 ile çarpımı olan 165, en düşük puan ise madde sayısının 1 ile çarpımı olan 55'tir. Yüksek puan almak, öğrencinin kendisini etkili ders çalışma becerileri açısından yeterli olarak algıladığına işaret etmektedir.

\section{İşlem}

Araştırmanın ilk aşamasında, ilgili yerli ve yabancı alan yazın taranmış (Akçamete ve diğ., 2002; Aksu ve Paykoç, 1995; Anday-Porter ve diğ., 2000; Arıkan, 1999; Baumgartner, Bryan, Donahue ve Nelson, 1993; Cone, Delawyer ve Wolfe, 1985; Demiroğlu-Memiş, 2007; Dodeen, 2008; Hughes, Schumm ve Vaughn, 1999; Dodge, 1994; Karabınar, 2000; Kiewra, 2002; McEwan, 1996; Sabornie, 2002; Serbest, 1991; Smith, 2000; Smith ve diğ., 2000; Strichart ve Mangrum, 2002; Thomas, 1993; Turnbough ve Christenberry, 1997; Uluğ, 1981, 2000; Yıldırım ve diğ., 2000) ve ölçeklerde öğrencilerin ders çalışma becerilerini gözlenebilir davranışlarla yansıtacağına inanılan ve ders çalışma becerilerinden; planlı çalışma, not tutma, etkili okuma, etkili yazma, ders dinleme, güdülenme, çalışma ortamını düzenleme, sınavlara hazırlanma, sınavlara girme ve ödev yapma alt boyutlarını içerdiği düşünülen ifadelerden bir madde havuzu oluşturulmuştur. $\mathrm{Bu}$ havuzdan ana-baba formuna uygun 69 , öğretmen 
formuna uygun 41 ve öğrenci formuna uygun 79 madde seçilerek ölçeklerin ilk halleri hazırlanmıştır.

Formlar numaralandırılmış, ayrı zarflara konulmuş ve uygulama için sınıf öğretmenlerine elden ulaştırılmıştır. Her sınıf öğretmeninden, sınıf listesinde yer alan ilk beş öğrenciyi değerlendirmesi istenmiştir. Öğretmenlerin değerlendirdikleri öğrencilerin ana-babalarına ve öğrencilerin kendilerine de, sınıf öğretmenleri tarafindan ilgili ölçeklerin ulaştırılıp yanıtlanması sağlanmıştır. Ankara ilinde bulunan katılımcıların formları, ikinci araştırmacı tarafından okullara gidilerek sınıf öğretmenlerinden toplanmış, Adana ve Kırıkkale'deki katılımcıların formları ise, okullardaki birer sınıf öğretmeni tarafindan posta yoluyla araştırmacılara ulaştırılmıştır. Uygun yanitlanmayan ve geri dönmeyen ölçeklerin elenmesiyle, 588 öğrenciden, 555 ana-babadan ve 98 sinıf öğretmeninden (öğretmenlerden toplam 389 ölçek geri alınmıştır) kullanılabilir veriler elde edilmiştir.

\section{Verilerin Analizi}

Toplanan veriler SPSS for Windows 10.0 ortamına aktarıldıktan sonra ölçeklerin geçerlik ve güvenirlik çalışmaları yapılmıştır. Öncelikle, ölçme araçlarının yapısal özelliklerini belirlemek amacıyla verilere Temel Bileşenler Analizi yoluyla Açımlayıcı Faktör Analizi tekniği uygulanmıştır. Ölçeklerin geçerlikleri için faktör analizinin dışında tüm test ve alt testler arası ikili korelasyon hesaplamaları ve \%27'lik alt ve üst grupların ilişkisiz ölçümler için $t$ - testi ile karşılaştırmaları yapılmıştır. Ölçeklerde yer alan maddelerin, ölçülmek istenen boyutu ölçme derecesini belirlemek amacıyla ise ölçeklere madde analizi yapılmıştır.

Ölçeklerin güvenirlik düzeylerini belirlemek amacıyla, ölçeklerin tüm ölçek ve alt ölçekler boyutunda Cronbach Alpha, iki yarım güvenirlik ve test-tekrar test güvenirlik katsayıları hesaplanmıştır. Üç bilgi kaynağından elde edilen puanlar arasındaki ilişkiler ise Pearson korelasyon katsayısı ile incelenmiş̧ir. Verilerin çözümlenmesinde 0.01 ve 0.05 anlamlılık düzeyleri benimsenmiştir (Green, Salkind ve Akey, 1997).

\section{BULGULAR}

\section{Çalışma Becerileri Değerlendirme Ölçeği / Ana-Baba Formu (ÇBDÖ/ABF)}

Geçerlik Çalışmaları: Ölçeğin yapı geçerliğini belirlemenin bir yolu olarak, elde edilen verilere Temel Bileşenler Analizi - TBA uygulanmıştır. İlk analizde özdeğerleri 1.00 'in üzerinde 16 faktör elde edilmiştir. $\mathrm{Bu}$ faktörler anlamlandırılamayınca analizler farklı sayıda faktörlere göre yinelenmiştir. Analizlerde ölçeğin 6 boyutlu bir yapıya sahip olduğu izlenimi 
edinilmesi üzerine, TBA 6 faktöre göre tekrarlanmıştır. Olabildiğince bağımsız faktörlere ulaşmak amacıyla analize bir dik döndürme - rotasyon yöntemi olan varimaks ile devam edilmiştir. Faktör yük değerleri 0.30'un altında olan ve birden fazla faktöre girip bu faktörler arasındaki farkların 0.10 ve daha az olduğu 26 madde elenmiş ve ölçeğin 43 maddeden oluşan son hali elde edilmiştir.

Analiz sonucunda, elde edilen 6 faktörün toplam varyansın \%48.18'ini açıkladığ1 gözlenmiştir. Sistemli ve Organize Çalışma-SOÇ olarak kavramsallaştırılan ilk faktör varyansın \%18.77'sini, Temizlik ve Düzen-TD olarak kavramsallaştırılan ikinci faktör varyansın \%7.32'sini, Çalışma Ortamı-ÇO olarak kavramsallaştırılan üçüncü faktör \%6.59'unu, $\boldsymbol{E v}$ Ödevleri-Ë̈ olarak kavramsallaştırılan dördüncü faktör \%6.04'ünü, Kaynaklara Başvurma-KB olarak kavramsallaştırılan beşinci faktör \% 5.19'unu, Dinlenme-D olarak kavramsallaştırılan son faktör ise varyansın \% 4.28'ini açıklamaktadır. Bu faktörlerin özdeğerleri sırasılya 11.22, 2.88, $2,08,1.76,1.44$ ve 1.35 'tir.

Ölçekte yer alan maddelerin ait oldukları faktörler, her faktörün açıkladığ1 varyans, özdeğerleri, faktör yük değerleri ve madde - toplam korelasyonları Tablo 1'de verilmiştir.

Tablo 1'de görüldüğü gibi, maddelerin ait oldukları faktör yük değerleri 1. faktör için $0.461-0.719$ arasında değişmektedir. $\mathrm{Bu}$ değerler diğer faktörler için sırayla $0.604-0.736,0.521-0.865,0.382-0.688,0.567-0.690$ ve 0.532-0.810 arasındadır. Madde-toplam korelasyonları incelendiğinde, bu korelasyonların 0.100 ile 0.677 arasında değiştiği gözlenmektedir. Bazı maddelerin $(31,37,56,67)$ madde test korelasyonları 0.20'nin altında bulunmuştur. Buna rağmen araştırmacılar, maddelerin özellikleri nedeniyle bu maddeleri ölçme aracında tutmaya karar vermişlerdir.

İlk analizlerde, maddelerin 1. faktör yük değerlerinin yüksek olması ve bu faktörün özdeğerinin (17.018) ve açıkladığı varyansın (\%24.664) yüksek olması, ölçeğin aynı zamanda toplam puan üzerinden de değerlendirilebileceğini göstermektedir.

Faktör analizi dişında ölçeğin geçerliğini belirlemenin bir diğer yolu olarak, alt \%27'lik grubun puanlaryyla, üst \%27'lik grubun puanları t-testi ile karşılaştırılmıştır. Analize göre elde edilen sonuçlar Tablo 2'de verilmiştir. 
Ders Çalışma Becerileri Ölçeği Ana-Baba, Öğretmen ve Öğrenci...

Tablo 1. ÇBDÖ/ABF'nin Faktör Yapısı ve Madde - Toplam Korelasyonları

\begin{tabular}{|c|c|c|c|c|c|c|c|}
\hline Faktör & $\begin{array}{c}\text { Madde } \\
\text { No }\end{array}$ & $\begin{array}{l}\text { Faktör } \\
\text { Yük } \\
\text { Değeri }\end{array}$ & $\begin{array}{c}\text { Madde - } \\
\text { Toplam } \\
\text { Korelasyonu }\end{array}$ & Faktör & $\begin{array}{c}\text { Madde } \\
\text { No }\end{array}$ & $\begin{array}{l}\text { Faktör } \\
\text { Yük } \\
\text { Değeri }\end{array}$ & $\begin{array}{c}\text { Madde - } \\
\text { Toplam } \\
\text { Korelasyonu }\end{array}$ \\
\hline \multirow{20}{*}{$\begin{array}{l}\text { 1. (SOÇ) } \\
(20 \\
\text { madde) } \\
\text { Özdeğer: } \\
11.22 \\
\text { Açıkladığı } \\
\text { Varyans: } \\
18.77\end{array}$} & 6 & 0.549 & 0.527 & \multirow{5}{*}{$\begin{array}{l}\text { 2. (TD) } \\
\text { (5 madde) } \\
\text { Özdeğer: } \\
2.88 \\
\text { Açıkladığı } \\
\text { Varyans: } \\
7.32\end{array}$} & 13 & 0.629 & 0.494 \\
\hline & 10 & 0.562 & 0.562 & & 27 & 0.646 & 0.445 \\
\hline & 16 & 0.516 & 0.606 & & 41 & 0.605 & 0.594 \\
\hline & 17 & 0.640 & 0.546 & & 64 & 0.604 & 0.453 \\
\hline & 18 & 0.577 & 0.551 & & 65 & 0.736 & 0.564 \\
\hline & 19 & 0.647 & 0.586 & \multirow{5}{*}{$\begin{array}{l}\text { 3. (ÇO) } \\
\text { (5 madde) } \\
\text { Özdeğer: } \\
2.08 \\
\text { Açıladığı } \\
\text { Varyans: } \\
6.59\end{array}$} & 47 & 0.843 & 0.282 \\
\hline & 20 & 0.696 & 0.502 & & 48 & 0.865 & 0.295 \\
\hline & 21 & 0.719 & 0.572 & & 50 & 0.522 & 0.418 \\
\hline & 22 & 0.515 & 0.503 & & 51 & 0.609 & 0.325 \\
\hline & 23 & 0.677 & 0.521 & & 52 & 0.521 & 0.325 \\
\hline & 25 & 0.613 & 0.557 & \multirow{5}{*}{$\begin{array}{l}\text { 4. }(\text { EÖ) } \\
\text { (5 madde) } \\
\text { Özdeğer: } \\
1.76 \\
\text { Açıkladığ1 } \\
\text { Varyans: } \\
6.04\end{array}$} & 29 & 0.382 & 0.355 \\
\hline & 43 & 0.493 & 0.449 & & 32 & 0.688 & 0.381 \\
\hline & 53 & 0.570 & 0.597 & & 33 & 0.660 & 0.487 \\
\hline & 54 & 0.545 & 0.562 & & 34 & 0.616 & 0.403 \\
\hline & 55 & 0.674 & 0.670 & & 35 & 0.460 & 0.358 \\
\hline & 57 & 0.634 & 0.628 & \multirow{5}{*}{$\begin{array}{l}\text { 5. (KB) } \\
\text { (5 madde) } \\
\text { Özdeğer: } \\
1.44 \\
\text { Açıladığ } 1 \\
\text { Varyans: } \\
5.19\end{array}$} & 31 & 0.567 & 0.100 \\
\hline & 59 & 0.548 & 0.569 & & 37 & 0.588 & 0.100 \\
\hline & 60 & 0.652 & 0.620 & & 39 & 0.690 & 0.401 \\
\hline & 61 & 0.461 & 0.269 & & 40 & 0.687 & 0.361 \\
\hline & 63 & 0.633 & 0.677 & & 56 & 0.576 & 0.152 \\
\hline & & & & \multirow{3}{*}{$\begin{array}{l}\text { 6. (D) } \\
\text { (3 madde) } \\
\text { Özdeğer: } \\
1.35 \\
\text { Açıkladığı } \\
\text { Varyans: } \\
4.28\end{array}$} & 62 & 0.662 & 0.411 \\
\hline & & & & & 67 & 0.532 & 0.183 \\
\hline & & & & & 68 & 0.810 & 0.334 \\
\hline
\end{tabular}


Tablo 2. ÇBDÖ/ABF Alt ve Üst \%27'lik Grupların Puan Ortalamalarının Karşılaştırılmasina

\begin{tabular}{|c|c|c|c|c|c|c|}
\hline ÇBDÖ/ABF & $\begin{array}{c}x \\
\text { (alt } \\
\% 27)\end{array}$ & $\begin{array}{c}\text { sS } \\
\text { (alt \%27) }\end{array}$ & $\begin{array}{c}x \\
\text { (üst } \\
\% 27 \text { ) }\end{array}$ & $\begin{array}{c}\text { ss } \\
\text { (üst } \\
\% 27 \text { ) }\end{array}$ & $\mathbf{t}$ & $\mathbf{p}$ \\
\hline Tüm test & 83.6 & 8.56 & 117.11 & 3.44 & 43.87 & $0.01 *$ \\
\hline SOÇ & 33.75 & 6.19 & 53.97 & 3.16 & 35.14 & $0.01 *$ \\
\hline TD & 11.40 & 2.30 & 14.73 & 0.70 & 16.73 & $0.01 *$ \\
\hline ÇO & 10.76 & 2.88 & 14.14 & 1.49 & 12.59 & $0.01 *$ \\
\hline EÖ & 10.29 & 2.20 & 13.58 & 1.42 & 15.19 & $0.01 *$ \\
\hline KB & 10.10 & 2.26 & 12.04 & 1.82 & 8.10 & $0.01 *$ \\
\hline D & 7.31 & 1.36 & 8.65 & 0.65 & 10.78 & $0.01 *$ \\
\hline
\end{tabular}

Tablo 2'de de görüldüğü gibi, tüm ölçek ve alt ölçekler, alt ve üst \%27'lik grupları 0.01 düzeyinde birbirinden ayırmaktadır. Dolayısıyla ÇBDÖ/ABF, çocuklarının ders çalışma becerilerini yeterli ve yetersiz olarak değerlendiren ana-babaları birbirinden ayırt edebilmektedir. $\mathrm{Bu}$ bulgu, ölçeğin ayırt edici geçerliğine ilişkin bir kanıt olarak değerlendirilmiştir.

Alt ölçeklerin birbirleriyle ve tüm test ile korelasyonları Tablo 3'te verilmiştir.

Tablo 3. ÇBDÖ/ABF Tüm Ölçek ve Alt Ölçekler Arası İkili Korelasyonlar

\begin{tabular}{|c|c|c|c|c|c|c|}
\hline ÇBDÖ/ABF & $\begin{array}{l}\text { SOÇ } \\
\text { r }\end{array}$ & $\begin{array}{l}\text { TD } \\
\mathbf{r}\end{array}$ & $\begin{array}{l}\text { ÇO } \\
\mathbf{r}\end{array}$ & $\begin{array}{l}\text { EÖ } \\
\mathbf{r}\end{array}$ & $\begin{array}{l}\text { KB } \\
\mathbf{r}\end{array}$ & $\begin{array}{l}\mathbf{D} \\
\mathbf{r}\end{array}$ \\
\hline Tüm test & $0.92 *$ & $0.72 *$ & $0.51^{*}$ & $0.65^{*}$ & $0.41^{*}$ & $0.48^{\prime}$ \\
\hline SOÇ & & $0.61 *$ & $0.27 *$ & $0.47 *$ & $0.25 *$ & $0.36^{*}$ \\
\hline TD & & & $0.28 *$ & $0.47 *$ & $0.16^{*}$ & $0.27^{*}$ \\
\hline ÇO & & & & $0.35 *$ & $0.18^{*}$ & 0.28 \\
\hline EÖ & & & & & $0.17 *$ & 0.24 \\
\hline $\mathbf{K B}$ & & & & & & 0.23 \\
\hline
\end{tabular}

Tablo 3'te de görüldüğü gibi, tüm alt ölçekler toplam ölçek puanı ile anlamlı korelasyon vermektedir. Özellikle SOÇ ve TD alt boyutlarının toplam puan ile çok yüksek korelasyon vermesi dikkati çekmektedir. $\mathrm{Bu}$ durum, ölçeğin aynı zamanda tek boyutlu olarak değerlendirilebileceğine ilişkin bir kanıt olarak düşünülebilir. 
Güvenirlik Çalışmaları: ÇBDÖ/ABF'nin güvenirliğini belirlemek amacıyla Cronbach Alpha iç tutarlılık, iki yarım güvenirlik ve test-tekrar test güvenirlik katsayıları hesaplanmış ve sonuçlar Tablo 4'te verilmiştir. ÇBDÖ/ABF'nin test-tekrar test güvenirlik çalışması, ölçeğin 4 hafta arayla 31 kişiye uygulanması şeklinde yürütülmüştür.

Tablo 4. ÇBDÖ/ABF Güvenirlik Katsayıları

\begin{tabular}{lccc}
\hline ÇBDÖ/ABF & Cronbach Alpha & $\begin{array}{c}\text { İki Yarım } \\
\text { Güvenirlik }\end{array}$ & $\begin{array}{c}\text { Test }- \text { Tekrar } \\
\text { Test }\end{array}$ \\
\hline Tüm test & 0.92 & 0.88 & $0.90^{*}$ \\
SOÇ & 0.92 & 0.89 & $0.89^{*}$ \\
TD & 0.80 & 0.71 & $0.66^{*}$ \\
ÇO & 0.76 & 0.67 & $0.73^{*}$ \\
EÖ & 0.68 & 0.61 & $0.54^{*}$ \\
KB & 0.65 & 0.70 & $0.71^{*}$ \\
D & 0.59 & 0.75 & $0.47^{*}$ \\
\hline
\end{tabular}

$* \mathrm{p}<0.01$

Tablo 4'te de görüldüğ̈̈ gibi, ÇBDÖ/ABF'nin Cronbach Alpha katsayıları 0.92-0.59 ve iki yarım güvenirlik katsayıları 0.89-0.61 arasında değişmektedir. Ölçeğin test-tekrar test güvenirlik katsayıları ise 0.90-0.47 arasındadır.

Katılımcıların ölçeklerden aldıkları puanların ortalamaları, standart sapmaları ve en düşük ile en yüksek puanları Tablo 5 'te sunulmuşstur.

Tablo 5. ÇBDÖ/ABF'nin Merkezi Dağılım ve Değişkenlik Ölçüleri

\begin{tabular}{lcccc}
\hline \multicolumn{1}{c}{ ÇBDÖ/ABF } & $\mathbf{x}$ & ss & En düşük puan & En yüksek puan \\
\hline Tüm test & 102.36 & 13.84 & 52 & 126 \\
SOÇ & 44.98 & 8.81 & 20 & 60 \\
TD & 13.45 & 2.03 & 6 & 15 \\
ÇO & 12.54 & 2.60 & 5 & 15 \\
EÖ & 12.21 & 2.22 & 5 & 15 \\
KB & 11.18 & 2.10 & 5 & 15 \\
D & 8.00 & 1.17 & 4 & 9 \\
\hline
\end{tabular}




\section{Çalışma Becerileri Değerlendirme Ölçeği / Öğretmen Formu (ÇBDÖ/ÖF)}

Geçerlik Çalışmaları: ÇBDÖ/ÖF'nin yapı geçerliğini belirlemek için elde edilen verilere TBA uygulanmıştır. İlk analizde özdeğerleri 1.00'in üzerinde 5 faktör elde edilmiştir. Bu faktörler anlamlandırılamayınca analizler farklı sayıda faktörlere göre yinelenmiştir. Analizler sonucunda ölçeğin 5 boyutlu bir yapıya sahip olduğu izlenimi edinilmesi üzerine, TBA 5 faktöre göre tekrarlanmış ve analize varimaks dik döndürme yöntemiyle devam edilmiştir. Faktör yük değerleri 0.30'un altında olan ve birden fazla faktöre girip bu faktörler arasındaki farkların 0.10 ve daha az olduğu 10 madde elenmiş ve ölçeğin 31 maddeden oluşan son hali elde edilmiştir.

Analiz sonucunda, elde edilen 5 faktörün toplam varyansın \%72.36'sını açıkladığı gözlenmiştir. Derse Katılım / Etkili Çalışma-DK/EÇ olarak kavramsallaştırılan ilk faktör varyansın \%25.72'sini, Temizlik ve Düzen-TD olarak kavramsallaştırılan ikinci faktör varyansın \%19.37'sini, Not Tutma / Sınava Girme-NT/SG olarak kavramsallaştırılan üçüncü faktör \%10.26'sını, Ödev Defteri Tutma-ÖDT olarak kavramsallaştırılan dördüncü faktör \%8.84'ünü, Okula Devam-OD olarak kavramsallaştırılan beşinci faktör ise varyansın \%8.16'sını açıklamaktadır. Bu faktörlerin özdeğerleri sırasıyla $17.11,1.83,1.32,1.16$ ve 1.02 'dir.

Ölçekte yer alan maddelerin ait oldukları faktörler, her faktörün açıkladığı varyans, özdeğerleri, faktör yük değerleri ve madde-toplam korelasyonları Tablo 6'da sunulmuştur.

Tablo 6'da da görüldüğü gibi, maddelerin ait oldukları faktör yük değerleri 1. faktör için 0.563-0.800 arasında değişmektedir. Bu değerler diğer faktörler için sırayla $0.553-0.762,0.542-0.645,0.616-0.852$ ve 0.693 0.760 arasındadır. Madde-toplam korelasyonları incelendiğinde ise, bu korelasyonların 0.845 ile 0.544 arasında değişsiği gözlenmektedir.

İlk analizlerde, maddelerin 1. faktör yük değerlerinin yüksek olması ve bu faktörün özdeğerinin (22.667) ve açıkladığı varyansın (\%55.29) yüksek olması, ölçeğin aynı zamanda toplam puan üzerinden de değerlendirilebileceğini göstermektedir. 
Tablo 6. ÇBDÖ/ÖF'nin Faktör Yapısı ve Madde - Toplam Korelasyonları

\begin{tabular}{|c|c|c|c|c|c|c|c|}
\hline Faktör & Madde No & $\begin{array}{l}\text { Faktör } \\
\text { Yük } \\
\text { Değeri }\end{array}$ & $\begin{array}{l}\text { Madde -Toplam } \\
\text { Korelasyonu }\end{array}$ & Faktör & Madde No & $\begin{array}{l}\text { Faktör } \\
\text { Yük } \\
\text { Değeri }\end{array}$ & $\begin{array}{l}\text { Madde -Toplam } \\
\text { Korelasyonu }\end{array}$ \\
\hline \multirow{2}{*}{$\begin{array}{l}\text { 1. (DKEÇ) } \\
\text { (12 madde) }\end{array}$} & 7 & 0.582 & 0.755 & \multirow{2}{*}{$\begin{array}{c}\text { 2. (TD) } \\
\text { (9 madde) }\end{array}$} & 3 & 0.695 & 0.773 \\
\hline & 15 & 0.677 & 0.808 & & 12 & 0.740 & 0.724 \\
\hline \multirow{3}{*}{$\begin{array}{c}\text { Özdeğer: } \\
17.109\end{array}$} & 16 & 0.713 & 0.748 & \multirow{3}{*}{$\begin{array}{c}\text { Özdeğer: } \\
1.826\end{array}$} & 14 & 0.607 & 0.606 \\
\hline & 17 & 0.752 & 0.774 & & 26 & 0.654 & 0.821 \\
\hline & 18 & 0.785 & 0.804 & & 36 & 0.720 & 0.786 \\
\hline \multirow{7}{*}{$\begin{array}{l}\text { Açıkladığı } \\
\text { Varyans: } \\
25.72\end{array}$} & 19 & 0.772 & 0.817 & \multirow{4}{*}{$\begin{array}{c}\text { Açılkladığı } \\
\text { Varyans: } \\
19.37\end{array}$} & 37 & 0.762 & 0.791 \\
\hline & 21 & 0.738 & 0.845 & & 38 & 0.553 & 0.811 \\
\hline & 23 & 0.800 & 0.780 & & 40 & 0.668 & 0.691 \\
\hline & 24 & 0.780 & 0.796 & & 41 & 0.648 & 0.686 \\
\hline & 25 & 0.780 & 0.788 & \multirow{3}{*}{$\begin{array}{c}\text { 4. (ÖDT) } \\
\text { (3 madde) } \\
\text { Özdeğer: } \\
1.158 \\
\text { Açıkladığı } \\
\text { Varyans: } \\
8.84\end{array}$} & 4 & 0.852 & 0.587 \\
\hline & 27 & 0.576 & 0.620 & & 5 & 0.844 & 0.611 \\
\hline & 28 & 0.563 & 0.812 & & 11 & 0.616 & 0.661 \\
\hline \multirow{5}{*}{$\begin{array}{c}\text { 3. (NTSG) } \\
\text { (5 madde) } \\
\text { Özdeğer: } \\
1.316 \\
\text { Açıkladığı } \\
\text { Varyans: } \\
10.26\end{array}$} & 8 & 0.645 & 0.674 & \multirow[b]{2}{*}{$\begin{array}{c}\mathbf{5 .}(\mathbf{O D}) \\
\text { (2 madde) } \\
\text { Özdeğer: } \\
1.021 \\
\text { Açıkladığ1 } \\
\text { Varyans: } \\
8.16\end{array}$} & 20 & 0.693 & 0.598 \\
\hline & 9 & 0.635 & 0.575 & & 39 & 0.760 & 0.544 \\
\hline & 29 & 0.611 & 0.671 & & & & \\
\hline & 31 & 0.631 & 0.577 & & & & \\
\hline & 33 & 0.542 & 0.707 & & & & \\
\hline
\end{tabular}

Faktör analizi dışında ölçeğin geçerliğini belirlemek için gerçekleştirilen alt ve üst $\% 27^{\prime}$ lik dilimde yer alan katılımcıların puanlarının karşılaştırıldığı t-testi sonuçları Tablo 7'de verilmiştir.

Tablo 7. ÇBDÖ/ÖF Alt ve Üst \%27'lik Grupların Puan Ortalamalarının Karşılaştırılmasına İlişskin t-testi Sonuçları

\begin{tabular}{lccccc}
\hline ÇBDÖ/ÖF & $\begin{array}{c}\mathbf{x} \\
\text { (alt \%27) }\end{array}$ & $\begin{array}{c}\text { ss } \\
\text { (alt \%27) }\end{array}$ & $\begin{array}{c}\mathbf{x} \\
\text { (üst \%27) }\end{array}$ & $\begin{array}{c}\text { ss } \\
\text { (üst \%27) }\end{array}$ & t \\
\hline Tüm test & 53.66 & 8.19 & 90.45 & 1.67 & $44.91^{*}$ \\
DKEÇ & 16.38 & 3.28 & 34.40 & 1.47 & $51.11^{*}$ \\
TD & 17.29 & 3.57 & 26.90 & 0.30 & $27.37^{*}$ \\
NTSG & 10.00 & 2.38 & 14.52 & 0.75 & $18.49^{*}$ \\
ÖDT & 5.13 & 1.74 & 8.63 & 0.83 & $18.53^{*}$ \\
OD & 4.86 & 1.19 & 5.99 & 0.10 & $9.72^{*}$ \\
\hline
\end{tabular}

$* \mathrm{p}<0.01$ 
Tablo 7'de de görüldüğü gibi, ÇBDÖ/ÖF tüm test ve alt testler boyutunda alt ve üst \%27'lik grupları 0.01 düzeyinde birbirlerinden ayırabilmektedir. $\mathrm{Bu}$ da ölçeğin geçerli bir ölçme aracı olduğunu ortaya koymaktadır. Alt ölçeklerin birbirleriyle ve tüm testle korelasyonları Tablo 8 'de verilmiştir.

Tablo 8. ÇBDÖ/ÖF Tüm Ölçek ve Alt Ölçekler Arası İkili Korelasyonlar

\begin{tabular}{lccccc}
\hline \multicolumn{1}{c}{ ÇBDÖ/ÖF } & DKEÇ & TD & NTSG & ÖDT & OD \\
& $\mathbf{r}$ & $\mathbf{r}$ & $\mathbf{r}$ & $\mathbf{r}$ & $\mathbf{r}$ \\
\hline Tüm test & $0.95^{*}$ & $0.92^{*}$ & $0.84^{*}$ & $0.73^{*}$ & $0.66^{*}$ \\
DKEÇ & & $0.80^{*}$ & $0.72^{*}$ & $0.62^{*}$ & $0.55^{*}$ \\
TD & & & $0.75^{*}$ & $0.62^{*}$ & $0.62^{*}$ \\
NTSG & & & $0.56^{*}$ & $0.59^{*}$ \\
ÖDT & & & & $0.45^{*}$ \\
\hline
\end{tabular}

$* \mathrm{p}<0.01$

Tablo 8'de de görüldüğü gibi, tüm alt ölçekler toplam ölçek puanı ile anlamlı ve yüksek korelasyon vermektedir. Bu durum, ölçeğin aynı zamanda tek boyutlu olarak değerlendirilebileceğine ilişkin bir kanıt olarak düşünülebilir.

Güvenirlik Çalışmaları: ÇBDÖ/ÖF'nin güvenirliğini belirlemek amacıyla Cronbach Alpha iç tutarlılık, iki yarım güvenirlik ve test - tekrar test güvenirlik katsayıları hesaplanmış ve sonuçlar Tablo 9'da verilmiştir. Ölçeğin test-tekrar test güvenirlik çalışması ölçeğin 4 hafta süreyle 30 kişiye uygulanması şeklinde yürütülmüştür.

Tablo 9. ÇBDÖ/ÖF Güvenirlik Katsayıları

\begin{tabular}{lccc}
\hline \multicolumn{1}{c}{ ÇBDÖ/ÖF } & Cronbach Alpha & İki Yarım Güvenirlik & Test - Tekrar Test \\
\hline Tüm test & 0.97 & 0.96 & $0.98^{*}$ \\
DKEÇ & 0.96 & 0.93 & $0.96^{*}$ \\
TD & 0.94 & 0.93 & $0.98^{*}$ \\
NTSG & 0.83 & 0.81 & $0.91^{*}$ \\
ÖDT & 0.86 & 0.79 & $0.93^{*}$ \\
OD & 0.74 & 0.76 & $0.97^{*}$ \\
\hline
\end{tabular}

$* \mathrm{p}<0.01$ 
Tablo 9'da da görüldüğü gibi, ÇBDÖ/ÖF'nin Cronbach Alpha katsayıları 0.97-0.74 ve iki yarım güvenirlik katsayıları 0.96-0.76 arasında değişmektedir. Ölçeğin test-tekrar test katsayıları ise 0.98 ile 0.91 arasında değerler almaktadır. Katılımcıların ölçeklerden aldıkları puanların ortalamaları, standart sapmaları ve en düşük ile en yüksek puanları Tablo 10 'da sunulmuştur.

Tablo 10. ÇBDÖ/ÖF'nin Merkezi Dağıllm ve Değişskenlik Ölçüleri

\begin{tabular}{lcccc}
\hline \multicolumn{1}{c}{ ÇBDÖ/ÖF } & $\mathbf{x}$ & ss & En düşük puan & En yüksek puan \\
\hline Tüm test & 76.02 & 15.26 & 35 & 93 \\
DKEÇ & 26.67 & 7.48 & 12 & 36 \\
TD & 23.46 & 4.53 & 10 & 27 \\
NTSG & 13.02 & 2.36 & 5 & 15 \\
ÖDT & 7.24 & 1.97 & 3 & 9 \\
OD & 5.64 & 0.82 & 2 & 6 \\
\hline
\end{tabular}

\section{Çalışma Becerilerini Değerlendirme Ölçeği / Öğrenci Formu - ÇBDÖ/ÖĞRF}

Geçerlik Çalışmaları: Ölçeğin yapı geçerliğini sınamak için yapılan TBA'da, ilk bulgulara göre özdeğerleri 1.00'in üzerinde 21 faktör elde edilmiştir. $\mathrm{Bu}$ faktörler anlamlandırılamayınca analizler farklı sayıda faktörlere göre yinelenmiştir. Analizler sonucunda ölçeğin 6 boyutlu bir yapıya sahip olduğu izlenimi edinilmesi üzerine, TBA 6 faktöre göre tekrarlanmış ve analize varimaks dik döndürme yöntemiyle devam edilmiştir. Faktör yük değerleri 0.30 'un altında olan ve birden fazla faktöre girip bu faktörler arasındaki farkların 0.10 ve daha az olduğu 24 madde elenmiş ve ölçeğin 55 maddeden oluşan son hali elde edilmiştir.

Analiz sonucunda, elde edilen 6 faktörün toplam varyansın \%36.41'ini açıkladığ1 gözlenmiştir. Etkili Ödev Yapma ve Sınavlara Hazırlanma$\boldsymbol{E} \boldsymbol{O} \mathbf{Y} / \boldsymbol{S H}$ olarak kavramsallaştırılan ilk faktör varyansın \%9.62'sini, Sistemli ve Organize Çalışma-SOÇ olarak kavramsallaştırılan ikinci faktör varyansın \%8.06'sın1, Öğrenmede Karşılaşılan Güçlükler-ÖKG olarak kavramsallaştırılan üçüncü faktör \%6.51'ini, Çalışma Ortamını DüzenlemeÇOD olarak kavramsallaştırılan dördüncü faktör \%4.38'ini, Yardım İstemeYi olarak kavramsallaştırılan beşinci faktör \%4.07'sini ve Düzenlilik ve Uygun Sınıf İçi Davranış-D/USD olarak kavramsallaştırılan altıncı faktör ise varyansın \%3.77'sini açıklamaktadır. Bu faktörlerin özdeğerleri sırasıyla $9.71,2.58,2.27,2.06,1.86$ ve 1.54 'tür. 
Ölçekte yer alan maddelerin ait oldukları faktörler, her faktörün açıkladığı varyans, özdeğerleri, faktör yük değerleri ve madde - toplam korelasyonları Tablo 11'de verilmiştir.

Tablo 11. ÇBDÖ/ÖĞRF'nin Faktör Yapısı ve Madde - Toplam Korelasyonları

\begin{tabular}{|c|c|c|c|c|c|c|c|}
\hline Faktör & $\begin{array}{c}\text { Madde } \\
\text { No }\end{array}$ & $\begin{array}{l}\text { Faktör } \\
\text { Yük } \\
\text { Değeri }\end{array}$ & $\begin{array}{c}\text { Madde - } \\
\text { Toplam } \\
\text { Korelasyonu }\end{array}$ & Faktör & $\begin{array}{c}\text { Madde } \\
\text { No }\end{array}$ & $\begin{array}{l}\text { Faktör } \\
\text { Yük } \\
\text { Değeri }\end{array}$ & $\begin{array}{c}\text { Madde - } \\
\text { Toplam } \\
\text { Korelasyonu }\end{array}$ \\
\hline \multirow{18}{*}{$\begin{array}{l}\mathbf{1 .} \\
\text { (EÖO/SH) } \\
\text { (18 madde) } \\
\text { Özdeğer: } \\
9.708 \\
\text { Açıladığı } \\
\text { Varyans: } \\
9.62\end{array}$} & 7 & 0.361 & 0.319 & \multirow{10}{*}{$\begin{array}{l}\text { 2. (SOÇ) } \\
(10 \\
\text { madde) } \\
\text { Özdeğer: } \\
2.583 \\
\text { Açıladı̆ı̆ } 1 \\
\text { Varyans: } \\
8.06\end{array}$} & 2 & 0.541 & 0.480 \\
\hline & 11 & 0.333 & 0.263 & & 4 & 0.562 & 0.555 \\
\hline & 13 & 0.390 & 0.300 & & 12 & 0.560 & 0.455 \\
\hline & 16 & 0.452 & 0.542 & & 17 & 0.501 & 0.477 \\
\hline & 22 & 0.452 & 0.435 & & 18 & 0.640 & 0.499 \\
\hline & 25 & 0.518 & 0.538 & & 19 & 0.587 & 0.424 \\
\hline & 31 & 0.450 & 0.363 & & 21 & 0.531 & 0.405 \\
\hline & 36 & 0.481 & 0.521 & & 45 & 0.516 & 0.272 \\
\hline & 38 & 0.479 & 0.423 & & 59 & 0.574 & 0.333 \\
\hline & 43 & 0.541 & 0.561 & & 72 & 0.503 & 0.462 \\
\hline & 44 & 0.374 & 0.294 & \multirow{8}{*}{$\begin{array}{l}\text { 4. (ÇOD) } \\
\text { (8 madde) } \\
\text { Özdeğer: } \\
2.061 \\
\text { Açıkladığ } 1 \\
\text { Varyans: } \\
4.38\end{array}$} & 6 & 0.336 & 0.180 \\
\hline & 47 & 0.625 & 0.418 & & 8 & 0.330 & 0.398 \\
\hline & 61 & 0.502 & 0.563 & & 26 & 0.398 & 0.362 \\
\hline & 63 & 0.553 & 0.510 & & 49 & 0.516 & 0.139 \\
\hline & 70 & 0.515 & 0.436 & & 52 & 0.440 & 0.320 \\
\hline & 71 & 0.464 & 0.423 & & 53 & 0.361 & 0.209 \\
\hline & 76 & 0.616 & 0.383 & & 65 & 0.508 & 0.393 \\
\hline & 77 & 0.520 & 0.482 & & 69 & 0.344 & 0.223 \\
\hline \multirow{10}{*}{$\begin{array}{l}\text { 3. (ÖKG) } \\
\text { (10 madde) } \\
\text { Özdeğer: } \\
2.268 \\
\text { Açıkladığ1 } \\
\text { Varyans: } \\
6.51\end{array}$} & 15 & 0.380 & 0.217 & \multirow{5}{*}{$\begin{array}{l}\mathbf{6 .} \\
\text { (D/USD) } \\
\text { (5 madde) } \\
\text { Özdeğer: } \\
1.543 \\
\text { Açıladı̆̆g } 1 \\
\text { Varyans: } \\
3.77\end{array}$} & 29 & 0.520 & 0.121 \\
\hline & 20 & 0.524 & 0.343 & & 37 & 0.548 & 0.285 \\
\hline & 23 & 0.572 & 0.304 & & 41 & 0.665 & 0.174 \\
\hline & 24 & 0.556 & 0.369 & & 62 & 0.393 & 0.379 \\
\hline & 28 & 0.614 & 0.457 & & 67 & 0.552 & 0.190 \\
\hline & 33 & 0.585 & 0.291 & & & & \\
\hline & 48 & 0.393 & 0.288 & & & & \\
\hline & 64 & 0.546 & 0.198 & & & & \\
\hline & 74 & 0.429 & 0.212 & & & & \\
\hline & 75 & 0.615 & 0.445 & & & & \\
\hline \multirow{4}{*}{$\begin{array}{l}\text { 5. (YI) } \\
\text { (4 madde) } \\
\text { Özdeğer: } \\
1.861 \\
\text { Açıladı̆̆ı } \\
\text { Varyans: } \\
4.07 \\
\end{array}$} & 39 & 0.602 & 0.131 & & & & \\
\hline & 40 & 0.731 & 0.220 & & & & \\
\hline & 56 & 0.709 & 0.158 & & & & \\
\hline & 60 & 0.410 & 0.373 & & & & \\
\hline
\end{tabular}


Tablo 11'de de görüldüğü gibi, maddelerin ait oldukları faktör yük değerleri 1. faktör için 0.333-0.625 arasında değişmektedir. Bu değerler diğer faktörler için sırayla 0.501-0.640, 0.380-0.615, 0.330-0.516, 0.4100.731 ve $0.393-0.665$ arasında değişmektedir. Madde - toplam korelasyonları incelendiğinde ise, bu değerlerin 0.563 ile 0.121 arasında değiştiği gözlenmektedir. Bazı maddelerin $(6,29,39,41,49,56,64,67)$ madde test korelasyonları 0.20 'nin altında bulunmuştur. Buna rağmen araştırmacılar, maddelerin özellikleri nedeniyle bu maddeleri ölçme aracında tutmaya karar vermişlerdir.

İlk analizlerde, maddelerin 1. faktör yük değerlerinin yüksek olması ve bu faktörün özdeğerinin (14.106) ve açıkladığı varyansın (\%17.86) yüksek olması, ölçeğin aynı zamanda toplam puan üzerinden de değerlendirilebileceğini göstermektedir.

Faktör analizi dışında ölçeğin geçerliğini belirlemek için alt ve üst \%27'lik dilimde yer alan puanların karşılaştırıldığı t-testi sonuçları Tablo 12 'de verilmiştir.

Tablo 12. ÇBDÖ/ÖĞRF Alt ve Üst \%27'lik Grupların Puan Ortalamalarının Karşılaştırlmasina İliş̧kin $t$ - testi Sonuçları

\begin{tabular}{lccccc}
\hline ÇBDÖ/ÖĞRF & $\begin{array}{c}\mathbf{x} \\
(\text { alt \%27) }\end{array}$ & $\begin{array}{c}\text { ss } \\
\text { (alt \%27) }\end{array}$ & $\begin{array}{c}\mathbf{x} \\
\text { (üst \%27) }\end{array}$ & $\begin{array}{c}\text { ss } \\
\text { (üst \%27) }\end{array}$ & t \\
\hline Tüm test & 117.73 & 9.18 & 149.60 & 4.45 & $37.22^{*}$ \\
EÖY/SH & 43.63 & 5.48 & 52.77 & 1.32 & $19.33^{*}$ \\
SOÇ & 17.35 & 3.50 & 25.35 & 2.67 & $21.66^{*}$ \\
ÖG & 19.70 & 3.37 & 25.84 & 2.80 & $16.69^{*}$ \\
ÇOD & 18.66 & 2.41 & 22.49 & 1.31 & $16.64^{*}$ \\
Yİ & 8.04 & 2.04 & 9.94 & 1.69 & $8.55^{*}$ \\
D/USD & 10.35 & 2.18 & 13.20 & 1.81 & $12.00^{*}$ \\
\hline
\end{tabular}

$* \mathrm{p}<0.01$

Tablo 12'de de görüldüğü gibi, tüm test ve alt test puan ortalamaları, alt ve üst \%27'lik dilimleri 0.01 düzeyinde birbirinden anlamlı olarak ayırmaktadır. Bir diğer deyişle, ÇBDÖ/ÖĞRF kendi ders çalışma becerilerini yeterli ve yetersiz olarak değerlendiren ilköğretim öğrencilerini birbirinden ayırt edebilmektedir. Bu bulgu, ölçeğin ayırt edici geçerliğine ilişkin bir kanıt olarak değerlendirilmiştir. Alt ölçeklerin birbirleriyle ve tüm test ile korelasyonları Tablo 13’te verilmiştir. 
Tablo 13. ÇBDÖ/ÖĞRF Tüm Ölçek ve Alt Ölçekler Arası İkili Korelasyonlar

\begin{tabular}{lcccccc}
\hline \multirow{2}{*}{ ÇBDÖ/ÖĞRF } & EÖY/SH & SOÇ & ÖKG & ÇOD & YI & D/USD \\
& $\mathbf{r}$ & $\mathbf{r}$ & $\mathbf{r}$ & $\mathbf{r}$ & $\mathbf{r}$ & $\mathbf{r}$ \\
\hline Tüm test & $0.85^{* *}$ & $0.78^{* *}$ & $0.65^{* *}$ & $0.64^{* *}$ & $0.39^{* *}$ & $0.46^{* *}$ \\
EÖY/SH & & $0.61^{* *}$ & $0.44^{* *}$ & $0.48^{* *}$ & $0.21^{* *}$ & $0.26^{* *}$ \\
SOÇ & & & $0.32^{* *}$ & $0.39^{* *}$ & $0.22^{* *}$ & $0.22^{* *}$ \\
ÖKG & & & & $0.31^{* *}$ & $0.09^{*}$ & $0.18^{* *}$ \\
ÇOD & & & & & $0.28^{* *}$ & $0.21^{* *}$ \\
Yİ & & & & & & $0.15^{* *}$ \\
\hline$* \mathrm{p}<0.05$ & $* * \mathrm{p}<0.01$ & & & & &
\end{tabular}

Tablo 13’te de görüldüğü gibi, tüm alt ölçekler toplam ölçek puanı ile anlamlı korelasyon vermektedir. Özellikle EÖY/SH, SOÇ ve ÖKG alt boyutlarının toplam puan ile yüksek korelasyon vermesi dikkati çekmektedir. $\mathrm{Bu}$ durum, ölçeğin aynı zamanda tek boyutlu olarak değerlendirilebileceğine ilişkin bir kanıt olarak düşünülebilir.

Güvenirlik Çalışmaları: ÇBDÖ/ÖĞRF'nin güvenirliğini belirlemek amacıyla Cronbach Alpha iç tutarlılık, iki yarım güvenirlik ve test-tekrar test güvenirlik katsayıları hesaplanmış ve sonuçlar Tablo 14 'te verilmiştir. Testtekrar test güvenirlik çalışması ölçeğin 4 hafta arayla 31 kişiye uygulanması şeklinde yürütülmüştür.

Tablo 14. ÇBDÖ/ÖĞRF Güvenirlik Katsayıları

\begin{tabular}{lccc}
\multicolumn{1}{c}{ ÇBDÖ/ÖĞRF } & Cronbach Alpha & İki Yarım Güvenirlik & Test - Tekrar Test \\
\hline Tüm test & 0.89 & 0.88 & $0.89^{*}$ \\
EÖY/SH & 0.86 & 0.85 & $0.84^{*}$ \\
SOÇ & 0.81 & 0.80 & $0.74^{*}$ \\
ÖKG & 0.74 & 0.71 & $0.60^{*}$ \\
ÇOD & 0.55 & 0.54 & $0.64 *$ \\
Yİ & 0.63 & 0.68 & $0.46^{*}$ \\
D/SİD & 0.56 & 0.56 & $0.58^{*}$ \\
\hline
\end{tabular}

$* \mathrm{p}<0.01$

Tablo 14'te de görüldüğü gibi, ÇBDÖ/ÖĞRF'nin Cronbach Alpha katsayıları $0.89-0.55$ ve iki yarım güvenirlik katsayıları $0.88-0.54$ arasında değişmektedir. Ölçeğin test-tekrar test katsayıları ise 0.89-0.46 arasındadır. 
Katılımcıların ölçeklerden aldıkları puanların ortalamaları, standart sapmaları ve en düşük ile en yüksek puanları Tablo 15 'te sunulmuştur.

Tablo 15. ÇBDÖ/ÖĞRF'nin Merkezi Dă̆llım ve Değişkenlik Ölçüleri

\begin{tabular}{lcccc}
\multicolumn{1}{c}{ ÇBDÖ/ÖĞRF } & $\mathbf{x}$ & ss & $\begin{array}{c}\text { En düşük } \\
\text { puan }\end{array}$ & $\begin{array}{c}\text { En yüksek puan } \\
\text { Tüm test }\end{array}$ \\
Ë̈Y/SH & 135.12 & 13.32 & 85 & 161 \\
SOÇ & 49.18 & 4.90 & 22 & 54 \\
ÖG & 21.79 & 4.14 & 10 & 30 \\
ÇOD & 22.76 & 3.86 & 10 & 30 \\
Yİ & 20.76 & 2.39 & 13 & 24 \\
D/USD & 8.90 & 1.94 & 4 & 12 \\
\hline
\end{tabular}

$C ̧ B D \ddot{O} / A B F, C ̧ B D O ̈ / O ̈ F$ ve ÇBDÖ/ÖĞRF Arasındaki İlişkilere Yönelik Bulgular

İlköğretim öğrencilerinin ders çalışma becerilerini değerlendirmeye yönelik geliştirilen ÇBDÖ/ABF, ÇBDÖ/ÖF ve ÇBDÖ/ÖĞRF'den alınan puanların birbirleriyle ilişkilerini incelemek amacıyla Pearson korelasyon katsayıları hesaplanmıştır. Ana-baba-öğretmen, ana-baba-öğrenci ve öğretmen-öğrenci puanları arasındaki korelasyon katsayıları sırasıyla 0.57, 0.70 ve 0.63 'tür $(p<0.01)$. Dolayısıyla, üç bilgi kaynağının değerlendirmeleri arasında tutarlılık gözlenmektedir. Tablo 16'da ölçeklerin ikili korelasyonlarının sonuçları yer almaktadır.

Tablo 16. ÇBDÖ/ABF, ÇBDÖ/ÖF ve ÇBDÖ/ÖĞRF İkili Korelasyon Katsayıları

\begin{tabular}{|c|c|c|c|c|}
\hline & $\mathbf{n}$ & $\mathbf{x}$ & ss & Pearson \\
\hline$C \zeta B D O ̈ / A B F$ & 85 & 100.36 & 15.08 & $0.57^{*}$ \\
\hline ÇBDÖ/ÖF & 85 & 73.33 & 18.94 & \\
\hline & $\mathbf{n}$ & $\mathbf{x}$ & ss & Pearson \\
\hline$C \zeta B D O ̈ / A B F$ & 85 & 100.36 & 15.08 & $0.70^{*}$ \\
\hline ÇBDÖ/ÖĞRF & 85 & 134.54 & 14.74 & \\
\hline & $\mathrm{n}$ & $\mathbf{x}$ & ss & Pearson \\
\hline 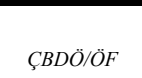 & 85 & 73.33 & 18.94 & $0.63^{*}$ \\
\hline ÇBDÖ/ÖĞRF & 85 & 134.54 & 14.74 & \\
\hline
\end{tabular}




\section{TARTIŞMA}

$\mathrm{Bu}$ araştırmada, ilköğretim öğrencilerinin ders çalışma becerilerinin, öğrenciler, ana-babalar ve öğretmenler olmak üzere farklı bilgi kaynakları tarafindan belirlenmesinde kullanılmak üzere üç ölçme aracı geliştirilmiş ve bu araçların geçerlik ve güvenirlik çalışmaları yapılmıştır. Burada öğrencilerin görüşleriyle birlikte, çok yönlü bir bakış açısı elde etmek bakımından, ana-baba ve öğretmenlerden de yönlendirici bilgiler almak hedeflenmiştir. Yabancı alan yazında da bu tür yaklaşımların olduğu dikkat çekmektedir (Anday-Porter ve diğ., 2000; Baumgartner ve diğ., 1993; Cone

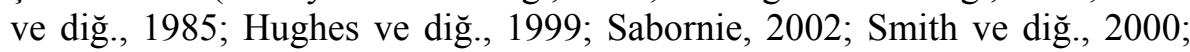
Soderlund ve Bursuck, 1995).

Ölçeklere ilişkin yapılan faktör analizi sonuçları, öğrenci ve ana-baba ölçeklerinin altı, öğretmen ölçeğinin ise beş faktörlü olduğuna işaret etmektedir. Araçlarda yer alan bazı faktörlerin de birbiriyle örtüştükleri görülmektedir. Ana-baba ve öğrenci ölçeklerinde Sistemli ve Organize Çalışma, Çalışma Ortamını Düzenleme, Düzenlilik ve Ödev Yapma alt boyutlarının ve ana-baba, öğretmen ve öğrenci ölçeklerinde de Temizlik ve Düzen alt boyutunun benzerlik gösterdiği dikkat çekmektedir. Ana-baba ve öğretmen ölçeklerindeki alt ölçek farklılıklarının, iki grubun öğrencileri ev ve okul gibi farklı ortamlardaki davranışlarına ilişkin beklentilerine göre değerlendirmelerinden kaynaklandığı düşünülmektedir.

Ölçeklerde ortaya çıkan faktörler, yerli ve yabancı alan yazında yer alan ölçme araçlarından farklı faktör yapıları göstermektedir (Anesko ve diğg., 1987: Akt., Sabornie, 2002; Cone ve di ̌̆., 1985; Anday-Porter ve diğ., 2000; Arıkan, 1999; Dodeen, 2008; Karabınar, 2000; Kiewra, 2002; Sabornie, 2002; Serbest, 1991; Smith ve diğ., 2000; Soderlund ve Bursuck, 1995; Strichart ve Mangrum, 2002). Bunun iki nedeni olduğu düşünülebilir. Bunlardan ilki, alan yazındaki ölçme araçlarının genellikle ders çalışma becerilerinin tümünden ziyade bir bölümünü değerlendirmeyi hedeflemeleridir. Örneğin bazı ölçekler yalnızca organize olma ya da ödev yapma gibi becerileri içermekte ve okuma ve ders dinleme gibi diğer ders çalışma becerilerinin alt boyutlarına ilişkin maddeler barındırmamaktadır (Anday-Porter ve di g., 2000; Arıkan, 1999; Karabınar, 2000; Kiewra, 2002; Sabornie, 2002; Serbest, 1991; Smith ve diğ., 2000; Soderlund ve Bursuck, 1995; Strichart ve Mangrum, 2002; Turnbough ve Christenberry, 1997; Uluğ, 1981; Xu, 2008). Diğer neden ise, alan yazındaki çoğu ölçme aracının hedef kitlesinin lise ve üniversite öğrencilerinden oluşmasıdır (Aksu ve Paykoç, 1995; Anday-Porter ve diğ., 2000; Arıkan, 1999; Dodeen, 2008; Karabınar, 2000; Kiewra, 2002; Serbest, 1991; Teker, 2002; Turnbough ve Christenberry, 1997; Xu, 2008). Yukarıda belirtilen farklılıkların yanı sıra, 
bu araştırmada geliştirilen ölçeklerle alan yazında yer alanlar arasında madde bazında benzerlikler göze çarpmaktadır. Bu benzerliklerin özellikle ödev yapma ve organize olma becerileriyle ilgili maddeleri içerdiği gözlenmektedir (Anday-Porter ve diğ., 2000; Anesko ve diğ., 1987: Akt., Sabornie, 2002; Akt., Cone ve diğ., 1985; Uluğ, 1981; Xu, 2008).

$\mathrm{Bu}$ araştırmada geliştirilen ana-baba, öğretmen ve öğrenci ölçeklerinde ortak olan bir unsur, üç ölçekte de ilk faktörlerin faktör yüklerinin ve açıkladığı varyansların yüksek olmasıdır. $\mathrm{Bu}$ bulgu, üç ölçeğin de alt ölçekler bazında puanlanabileceği gibi, toplam puan üzerinden de değerlendirilebileceğine yönelik güçlü bir kanıt niteliğindedir. Buna ilişkin bir diğer kanıt da, madde-toplam puan korelasyonlarının yüksek olmasıdır. $\mathrm{Bu}$, maddelerin toplam puanı yordama güçlerinin yüksek olduğunun bir kanıtıdır. Bu bulgu, aynı zamanda ölçeklerin yapı geçerliklerine ilişkin de bir kanıt niteliği taşımaktadır.

Ölçeklerin ayırt edici geçerliklerini belirlemek için gerçekleştirilen alt ve üst \%27'lik grupların karşılaştırılmasına ilişkin t-testi sonuçlarına bakıldığında, her üç ölçeğin de çalışma becerileri yüksek olanları, çalışma becerileri düşük olanlardan ayırt ettiği gözlenmiştir. Bu bulgular, ölçeklerin geçerli ölçme yapabildiklerinin bir kanıtı olarak düşünülebilir. İleri araştırmalarda, bu ölçeklerin özel gereksinimli olan ve olmayan, davranış problemleri olan ve olmayan ve okul başarısı düşük ve yüksek olan öğrenci gruplarında uygulanarak, ölçeklerin ayırt edici geçerliklerine ilişkin daha fazla kanıt elde edilebilir.

$\mathrm{Bu}$ araştırmanın hedef kitlesini ilköğretim öğrencileri ile bu öğrencilerin ana-babaları ve öğretmenleri oluşturmaktadır. Ülkemizde bu gruba yönelik geliştirilen çalışma becerileri ölçme araçları bulunmadığından, ölçeklerin ölçüt geçerliğine ilişkin bir uygulama yapmak mümkün olmamıştır. Uluğ'un (1981) geliştirdiği Çalışma Alışkanlıkları Envanteri yalnızca 8. sınıf öğrencilerine yönelik olduğundan, Demiroğlu-Memiş̧in (2007) ilköğretim öğrencileri için uyarladığı Çalışma Alışkanlıkları ve Tutumları Anketi (Survey of Study Habits and Attitudes - Brown / Holtzman, 1984; Akt., Demiroğlu-Memiş, 2007) ise, öğretmene yönelik öğrenci tutumları gibi farklı alt boyutları içermesinden dolayı geliştirdiğimiz ÇBDÖ/ÖĞRF'nin ölçüt geçerliğini sınamada kullanılmamıştır. Ancak, her ne kadar tümüyle özdeş alt ölçeklerden oluşmasalar da ana-baba, öğretmen ve öğrenci ölçekleri arasındaki korelasyonların anlamlı oluşu ölçeklerin yapı geçerliğinin bir işareti olarak düşünülebilir.

Güvenirliklere ilişkin bulgular incelendiğinde, ölçeklerin psikometrik özelliklerinin yeterli düzeyde olduğu görülmektedir. Cronbach Alpha, yarım 
test güvenirlik ve test-tekrar test güvenirlik katsayıları, üç ölçeğin de tüm test ve alt test boyutunda yüksek güvenirliğe sahip olduğunu göstermektedir.

Öğrencilerin ders çalışma becerilerinin üç grup tarafindan değerlendirilmesi arasındaki ikili korelasyon sonuçları, bu bilgi kaynaklarının değerlendirmeleri arasında tutarlılık olduğunu göstermektedir. Buna karşın, alan yazın incelendiğinde, üç bilgi kaynă̆ının öğrencilerin ders çalışma becerilerini değerlendirmelerine ilişkin bulgularda farklılıklar olduğu görülmektedir. Anday-Porter ve diğerlerinin (2000) araştırmasında, ana-babaların ve öğrencilerin yanıtlarının birbirleriyle örtüştüğü ve her iki grubun değerlendirmelerinin, öğretmen değerlendirmeleriyle çeliştiği belirlenmiştir. Benzer sonuçlara, Smith ve diğerlerinin (2000) çalışmasında da rastlanmaktadır. Söz konusu çalışmada, ana-babaların ve öğrencilerin değerlendirmeleri örtüşürken, öğretmenler ana-babalara kıyasla, öğrencilerin daha farklı alanlarda yetersizlikler sergilediklerini bildirmişler ve onları ders çalışma becerileri bakımından daha yetersiz olarak algılamışlardır. Stone (1997) ise, yukarıda anılan bulguların tersine, ana-babaların diğer iki gruba göre daha kötümser bir tablo çizdiklerini ortaya koymuştur. Her üç araştırmada ortak olan bir unsur, ana-baba ve öğrenci değerlendirmelerinin, öğretmen görüşlerine kıyasla daha fazla örtüşmeleridir. Çalışmamızda, sözü geçen araştırmalardan farklı olarak, üç bilgi kaynağ 1 da benzer değerlendirmeler ortaya koymuşlardır. $\mathrm{Bu}$ farkın nedeni, yukarıdaki araştırmalarda katılımcıların önemli bir bölümünün 14-17 yaş grubu öğrencilerinden oluşması ve dolayısıyla farklı bir yaş grubunu içermesi olabilir. Ayrıca, bu araştırmalarda ögrencilerin yeterli ve yetersiz oldukları ders çalışma becerilerinin hangileri olduğu tek tek belirlenmiş ve gruplar arası farklılıklar bu bağlamda tartışılmıştır. Çalışmamızda ise, bulgulara toplam puanlar üzerinden ulaşılmıştır. Çocukları farklı ortamlarda gözlemleyen ve onlara ilişkin farklı beklentileri olan ana-babalar ve sınıf öğretmenlerinin değerlendirmelerine ilişkin daha kapsamlı bir bakış açısı elde edebilmek için, belki de diğer çalışmalarda olduğu gibi ders çalışma becerilerinin her birinin ayrı ayrı incelenmesi gerekmektedir. Böylece, iki grubun görüşleri arasındaki olası farklılıkları gözleme olanağı olacaktır. Bu çalışmada bu tür bir karşılaştırmaya gidilmemiş olması bir sınırlılık gibi görünmektedir ve bu sınırlılığın ileriki çalışmalarda giderilmesi faydalı olacaktır. İleri araştırmalarda ayrıca, ana-baba, öğretmen ve öğrencilerin, öğrencilerin ders çalışma becerilerini değerlendirmeleri arasındaki ilişkilerin farklı özellikleri olan öğrenciler üzerinde, farklı gelişimsel dönemleri de içerecek şekilde yeniden incelenmesi, bu konudaki bilgileri zenginleştirecek ve etkili çalışma becerileri geliştirme çalışmalarına temel oluşturacaktır. 


\section{SONUÇ}

$\mathrm{Bu}$ araştırmada, ilköğretim öğrencilerinin ders çalışma becerilerini değerlendirmede ana-baba, öğretmen ve ilgili diğer mercilere yol göstermek için ders çalışma becerileri ölçme araçları geliştirilmiştir. ÇBDÖ/ABF, ÇBDÖ/ÖF ve ÇBDÖ/ÖĞRF'nin geçerlik ve güvenirlik çalışmaları, ölçeklerin yeterli psikometrik özelliklere sahip oldukları sonucunu doğurmaktadır. Buna göre ölçeklerimiz, üç bilgi kaynağından da öğrencilerin ders çalışma becerilerine ilişkin sağliklı bilgiler elde edilebileceğini ve bu bilgilerin gerekli müdahaleleri başlatmada yol gösterici olacağını düşündürmektedir.

Ders çalışma becerilerini değerlendirmeye yönelik geliştirilen ölçme araçlarına ilişkin alan yazına genel olarak bakıldığında, ölçme araçlarının yaklaşık yetmiş y1llık bir geçmişe dayandığ 1 ve hedef kitlenin çoğunlukla lise ve üniversite öğrencileri olduğu görülmektedir. İlköğretim öğrencilerinin ders çalışma becerilerinin kapsamlı olarak değerlendirilmesi ve buna bağlı olarak yapılandırılmış programların geliştirilmesi konusunda ülkemizde yaşanan sinırlılığı azaltmak amacıyla geliştirdiğimiz ölçeklerin, bu konuda ileri araştırmalara ve müdahale programlarına 1şık tutacağına inanmaktayız.

\section{KAYNAKLAR}

Akçamete, G., Gürgür, H., Kış, A., \& Kayaoğlu, H. (2002). Kaynaştırma programlarına yerleştirilmiş özel gereksinimli öğrencilerin okuma yazma güçlükleri. XII. Ulusal Özel Eğitim Kongresi, YöntemlerYaklaşımlar-Stratejiler. Ankara: Ankara Üniversitesi, Eğitim Bilimleri Fakültesi Yayınları, 271-288.

Aksu, M., \& Paykoç, F. (1995). Study skills and study habits of METU students. Paper Presented at the 6th European Conference for Research on Learning and Instruction. August 26-31, Nijmegen, Holland.

Anday-Porter, S., Henne, K., \& Horan, S. (2000). Improving student organizational skills through the use of organizational skills in the curriculum. Chicago: Saint Xavier University and SkyLight Professional Development. (ERIC) ED 442139.

Arıkan, F.T. (1999). English language instructors' perceptions of freshmen students' study skills at Bilkent University. Unpublished master's thesis. Bilkent University, Department of English Language Education, Ankara.

Babadoğan, C. (Ekim, 2002). Ders çalış1lır mı? Çoluk Çocuk, 19, 25-26. 
Baumgartner, D., Bryan, T., Donahue, M., \& Nelson, C. (1993). Thanks for asking: Parent comments about homework, tests and grades. Exceptionality, 4(3), 177-185.

Cone, J.D., Delawyer, D.D., \& Wolfe, V.V. (1985) Assessing parent participation: The parent / family involvement index. Exceptional Children, 51(5), 417-424.

Demiroğlu-Memiş, A. (2007). Öğrencilerin çalışma oryantasyonlarını etkileyen demografik faktörler. Türk Eğitim Bilimleri Dergisi, 5(2), 291-321.

Dodeen, H. (2008). Assessing test-taking strategies of university students: Developing a scale and estimating its psychometric indices. Assessment \& Evaluation in Higher Education, 33(4), 409-419.

Dodge, J. (1994). The study skills handbook: More than 75 strategies for better learning. New York: Scholastic Inc.

Gettinger, M., \& Seibert, J.K. (2002). Contributions of study skills to academic competence. School Psychology Review, 31(3), 350-365.

Green, S.B., Salkind, N.J., \& Akey, T.M. (1997). Using SPSS for Windows: Analyzing and understanding data. Upper Saddle River: Prentice Hall.

Hughes, M.T., Schumm, J.S., \& Vaughn, S. (1999). Home literacy activities: Perceptions and practices of Hispanic parents of children with learning disabilities. Learning Disability Quarterly, 22, 224-235.

Karabınar, S. (2000). A study on the relationships between self-concept, study skills and achievement in foreign language learning at university level. Unpublished doctoral thesis, Middle East Technical University, Graduate School of Social Sciences, Ankara.

Kiewra, K.A. (2002). How classroom teachers can help students learn and them how to learn. Theory Into Practice, 41(2), 71-80.

McEwan, E.K. (1996). Ödevimi köpekler kaptı: Çocuğunuzun ödev sorunlarıyla başa çıkmanın yolları, ana-babalara pratik öneriler. (Çev. Şerife Küçükal). Ankara: HYB Yayıncılık.

Sabornie, E.J. (2002). Homework and students with emotional and behavioral disorders. In K.L. Lane, F.M. Gresham \& O'Shaughnessy (Eds), Interventions for children with or at risk for emotional and behavioral disorders (144-158). Boston: Allyn \& Bacon.

Serbest, C. (1991). The influence of students' study skills on their academic achievement in English: A case study. Middle East Technical University, Graduate School of Social Sciences, Ankara. 
Smith, C.B. (2000). Reading to learn: How to study as you read. Bloomington: ERIC Clearinghouse on Reading, English and Communication, Indiana University.

Smith, M., Teske, R., \& Gossmeyer, M. (2000). Improving student achievement through the enhancement of study skills. Chicago: Saint Xavier University and SkyLight Professional Development. (ERIC) ED 441256.

Soderlund, J., \& Bursuck, B. (1995). A comparison of the homework problems of secondary school students with behavior disorders and nondisabled peers. Journal of Emotional and Behavioral Disorders, 3(3), 150-155.

Stone, C.A. (1997). Correspondence among parent teacher and student perceptions of adolescents' learning. Journal of Learning Disabilities, 30(6), 660-669.

Strichart, S.S., \& Mangrum, C.T. (2002). Teaching learning strategies and study skills to students with learning disabilities, attention deficit disorders or special needs (3rd Edition). Boston: Allyn \& Bacon.

Teker, N. (2002). Uzaktan eğitim öğrencilerinin ders çalışma stratejilerinin karşılaştırılması. Eğitim Bilimleri ve Uygulama, 1(1), 49-66.

Thomas, A. (1993). Study skills. Eugene, Oregon: Oregon School Study Council, University of Oregon. (ERIC) ED 355616.

Turnbough, R.M. \& Christenberry, N.J. (1997). Study skills measurement: Choosing the most appropriate instrument. Paper Presented at the 26th Annual Meeting of the Mid-South Educational Research Association. November 12-14, New Orleans. (ERIC) ED 416207.

Uluğ, F. (1981). Verimli çalışma alışkanlıkları kazandırma konusunda yapılan rehberliğin okul başarısına etkisi. Yayınlanmamış yüksek lisans tezi, Ankara Üniversitesi, Eğitim Bilimleri Fakültesi, Ankara.

Uluğ, F. (2000). Okulda başarı: Etkili öğrenme ve ders çalışma yöntemleri (7. Basım). İstanbul: Remzi Kitabevi.

Xu, J. (2008). Validation of scores on the Homework Management Scale for high school students. Educational and Psychological Measurement, 68(2), 304-324.

Yeşilyaprak, B. (2000). Eğitimde rehberlik hizmetleri. Ankara: Nobel Yayıncilik.

Yıldırım, A., Doğanay, A., \& Türkoğlu, A. (2000). Okulda başarı için ders çalışma ve ögrenme becerileri. Ankara: Seçkin Yayıncılık. 